\title{
Study of the Cytotoxicity Effect of New Co(II) and Mn(II) Complexes of Flavon on Cancer (Cell Line RD) and Antimicrobial Activity
}

\author{
Omar H. Al-Obaidi \\ Chemistry Department, Education College for Girls, Al-Anbar University, Ramadi, Iraq \\ Email address: \\ dromaralobaidi@yahoo.com \\ To cite this article: \\ Omar H. Al-Obaidi. Study of the Cytotoxicity Effect of New Co(II) and Mn(II) Complexes of Flavon on Cancer (Cell Line RD) and \\ Antimicrobial Activity. Journal of Cancer Treatment and Research. Vol. 5, No. 2, 2017, pp. 19-23. doi: 10.11648/j.jctr.20170502.14
}

Received: September 17, 2016; Accepted: October 12, 2016; Published: March 22, 2017

\begin{abstract}
A new series of $\mathrm{Co}(\mathrm{II})$ and $\mathrm{Mn}(\mathrm{II})$ complexes with the Flavone ligand were studied on the growth of Rhabdomyo sarcomas (RD) cell Line in human by using in vitro system and compared with anticancer drug cisplatin (cis-pt) as appositive control. The cancer cells were treated with different concentration and cis-pt after $72 \mathrm{hr}$. exposure time. The cytotoxic activity was tested by inhibition rate as parameter. The results showed significant differences $(\mathrm{p}<0.05)$ for each three treatments when the inhibition rates were increased. The synthesized compounds were tested for antimicrobial activity by cup plate diffusion method. The results indicate the enhanced activity of metal complexes over the parent ligands.
\end{abstract}

Keywords: Flavone, Complexes, Antimicrobial Activity, Cytotoxicity Cisplatin

\section{Introduction}

Flavonoids represent one of the largest groups of natural products. In addition to the various functions of flavonoids in plants, their widespread distribution in nature, their structural variability, their relatively low toxicity, and their antioxidant activities have increased the interesting flavonoids as beneficial for human health.

Several therapeutically interesting biological activities of certain flavonoids have been reported including antibacterial [1], antiviral, anti-inflammatory [2, 3], antiallergic [4], antithrombotic [5], antimutagenic, antineoplastic [6], neuroprotective properties [7], and antioxidant properties [8, 9], etc. The biological activity of flavones can be modified upon formation of metal complexes.

Flavonoid-metal complex compounds are the subject of our long time research during which we investigated properties, composition, complex formation features, stability constants, as well as analytical appraisal of approximately 40 complexes of flavonoids from different flavonoid subclasses with a number of metal ions or metal groups $[10,11]$. The biological effects of flavonoid-metal complexes, confirmed by other authors in numerous studies, showed that complexes are more effective then free flavonoids. All these data are available in various previous publications $[12,13]$.

The synthesized ligand and metal chelates have been screened for in vitro antibacterial activity against Escherichia coli and Staphylococcus aureus, and new prepared complexes were compared with anticancer drug cis-platin.

\section{Experimental}

\subsection{Instrumentation and Chemical}

IR spectra were recorded Pye Unicam Sp. 3100 spectrophotometer, solid samples were measured as $\mathrm{KBr}$ disc. For UV measurement absolute methanol and ethanol were used as solvents. Rotary evaporator RE-120 Buchi. Gallenkamp (hot stage) determined M. P. BDH chemicals Ltd.-England, Fluka AG Buchs-Swaziland and Riedel Du Haen Germany supplied chemicals. (Cis-platin) $(10 \mathrm{mg} / 20 \mathrm{ml})$ was provide by Ebew (Austria).

\subsection{Preparation of Ligand and Their Complexes}

New complexes Co-L and Mn-L were provide by our study [14] $10 \mathrm{mg}$ of each complex dissolved in $20 \mathrm{ml}$ of 
normal saline (stock solution) and were stored at (2-8) $\mathrm{C}^{\mathrm{o}}$ until processing.

\subsubsection{General Procedure for the Preparation of Flavone- Mannose, 5-hydroxy-2-(4-(( $(2 R, 3 S, 4 S, 5 S, 6 S)-3,4,5,6-$ tetrahydroxytetrahydro-2H-pyran-2- yl)methoxy)phenyl)-4H-chromen-4-one (L)}

Take $(1 \mathrm{~mol})$ of Flavone 5-hydroxy-2-(4-hydroxyphenyl)$4 \mathrm{H}$-chromen-4-one and dissolved in $(200 \mathrm{ml})$ of DMSO and placed inside round flask capacity $(100 \mathrm{ml})$ then add $(1 \mathrm{~mol})$ of dissolved Mannose in $(20 \mathrm{ml})$ of the same solvent and added drops of $(5 \%)$ of $\mathrm{HCl}$, the mixture heated for two hours in a water bath and then the solvent is evaporated and collects the output. spectral data of these compounds are given as follows: (yield 65\%); FT-IR (KBr): 3401 (Ar-OH), due to presence of phenolic $-\mathrm{OH}$ group, $1600(\mathrm{C}=\mathrm{O}$ pyrone ring) $\mathrm{cm}^{-1}$; UV-Vis shows max (EtOH) $250 \mathrm{~nm}, 280 \mathrm{~nm}$ and 350 nm. C. H. N. analysis cal. C, 60.58; H, 4.84\%. Found: C, $60.71 ; \mathrm{H}, 4.33 \%$.

\subsubsection{General Procedure for the Preparation of the Complexes}

0.2 mmoles from $\mathrm{L}\left(\mathrm{C}_{21} \mathrm{H}_{20} \mathrm{O}_{9}\right)$ was dissolved in $\mathrm{MeOH}$ $(30 \mathrm{ml})$ then 0.1 mmole metal chlorides was added. The resulting mixture was refluxed for $30 \mathrm{~min}$. and the volume of the final mixture was reduced under vacuum. The crude products were purified by recrystallization from $\mathrm{MeOH}$ to give a powder, yield $82 \%$. Fig. 1 .

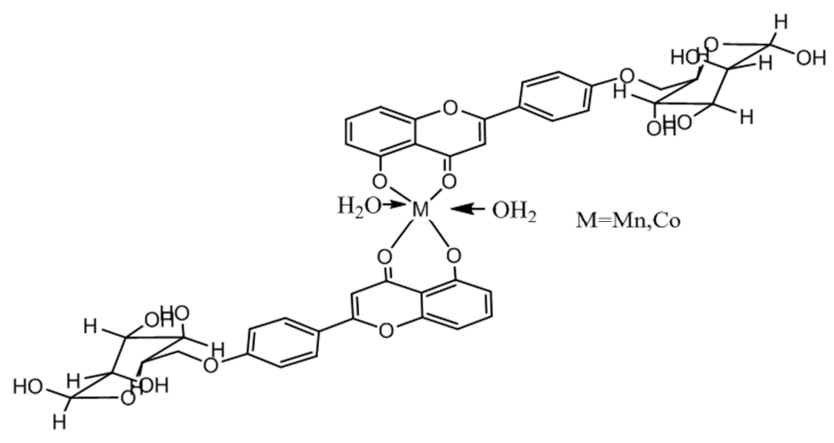

Figure 1. Suggested structure of the Co(II) and Mn(II) complexes.

\subsection{Study of Cytotoxic Effect on Cancer Cell Line}

One type of cancer cell lines have been used to study the impact of the prepared compounds under study on the growth of cells in laboratory and thus know the specifications of extracts as an anti-tumors, this work done at Department of Cancer Research in Bio-technology Research Centre, University of Nahrain.

All solutions are prepared at the same centre and culturing tissues were studied in vitro under optimum conditions by the same centre. The growth media used in tissue culture technique was MEM (Minimum Essential Media) was provided by Fetal Calf Serum (10\%) to form a confluent monolayer, then Subculture to discard the previous growth medium and the cell washed with sterilized phosphate buffer solution (PBS) by autoclave at $121^{\circ} \mathrm{C}$ for $15 \mathrm{~min}$ and addition 2-3 min and moving the culture flask kindness. The trypsin-versene solution to discard and cells incubated at $37^{\circ} \mathrm{C}$ until the cell separation from ground flask, added new growth media and redistribution of cells at the microtiter and incubated at $37^{\circ} \mathrm{C}[15]$.

\subsection{Cytotoxic or Cell Growth Inhibition Assay}

In this assay, the cell line (RD) was treated with new complexes and cisplatin by using four concentrations $(31.25,62.5,125,250) \mu \mathrm{g} / \mathrm{ml}$. immediately by adding of $25 \mathrm{ml}$ trypsin-versene solutions in to culture bottle and 20 $\mathrm{ml}$ of culture medium which contains $10 \%$ of serum to provide the suspend cells, mixed very well and addition of $0.2 \mathrm{ml}$ to each microtiter. The plates were incubated at $37^{\circ} \mathrm{C}$ for 24 hour until to form monolayer, then the previous culture medium which present in to the plates to discard 0.2 $\mathrm{ml}$ of compounds under study were added and these three preparation repeated as negative control (cancer cell line $\mathrm{RD}$ with buffer solutions) and incubated at $37^{\circ} \mathrm{C}$ for 72 hour exposure time. The culture medium to discard from micro litre plates, about $0.2 \mathrm{ml}$ of crystal violet solution was added to wells and the plates were incubated for $20 \mathrm{~min}$ at $37^{\circ} \mathrm{C}$. The plates washed gently with distilled water and left to dry. In the end of assay the plates were examined by ELISA reader at $492 \mathrm{~nm}$ transmitting wave length. Only viable cells were able to take a stain while the dead cells were not. The inhibition rate was measured according to were Gao. et al [16] and as follows:

Inhibition rate $\%=($ Abs. of negative control $-\mathrm{Abs}$. of Test $/$ Abs. of negative control) $\times 100$

\subsection{Antibacterial Activity}

Agar-well diffusion method followed as the using of kirby Baauer method [17] in the measurement of the sensitivity of bacteria used in this research for various concentrations of compounds, Escherichia Coli and aurous Staphylococcus bacteria was obtained (isolated and diagnosed in culture laboratory in children's hospital in Ramadi). also we used Mueller Hinton agar to test the sensitivity of bacteria for compounds and it was prepared as company instruction process, then the dishes putted in incubator at $(37)^{\circ} \mathrm{C}$ for (24) hours and inhibition diameter was then measure (Inhibition Zone) in each hole by ruler and record the results.

\section{Result and Discussion}

The flavone have been synthesized through on cyclization in alkaline $\mathrm{H}_{2} \mathrm{O}_{2}$ yielded5-hydroxy-2-(4hydroxyphenyl)-4H-chromen-4-one, which react with mannose to produce, 5-hydroxy-2-(4- $(((2 \mathrm{R}, 3 \mathrm{~S}, 4 \mathrm{~S}, 5 \mathrm{~S}, 6 \mathrm{~S})-$ 3,4,5,6-tetrahydroxy tetrahydro-2H-pyran-2-yl)methox y)phenyl)-4H-chromen-4-one(L). Complexes formation between $\mathrm{Co}(\mathrm{II})$ or $\mathrm{Mn}(\mathrm{II})$ chlorides and 5-hydroxy-2-(4$(((2 \mathrm{R}, 3 \mathrm{~S}, 4 \mathrm{~S}, 5 \mathrm{~S}, 6 \mathrm{~S})-3,4,5,6$-tetra hydroxytetrahydro-2Hpyran-2-yl) methoxy) phenyl)-4H-chromen-4-one(L) performed in ethanolic dimethyl formamide show the 
formation of mononuclear complexes with 1:2 metal to ligand stoichiometry (Fig. 1). Prepared ligand have been characterized by spectroscopic methods (UV-Vis, IR) and C. H. N. analysis.

\subsection{FT-IR Spectra}

The characteristic infrared spectral assignment of ligand (L) and their complexes are reported in experimental section. In the FT-IR spectra of ligand (L), the presence of phenolic $\mathrm{OH}$ and carbonyl group are confirmed by peaks at 3401 and $1600 \mathrm{~cm}^{-1}$ respectively [17]. However, in the spectra of the complexes there is complete disappearance of peak at $3401 \mathrm{~cm}^{-1}$ suggesting absence of phenolic $\mathrm{OH}$ group indicates its coordination. The band assigned to the carbonyl group is shifted to a lower wave number comparing with that of the free ligand, proving its coordination.

\subsection{UV-Vis. Spectra and Conductivity Measurements}

The UV-VIS. spectra of the complexes expected differences in the position of the absorption bands between the ligand and the related complexes, which are due to the coordination between the ligand and the transition metals. Appearance of new absorption maxima is considered as a hint for the formation of complexes. The bathochromic shift in band I upon coordination is due to the electronic transition $\left(\mathrm{n} \rightarrow \pi^{*}\right)$ of the lone pair of electrons of the hydroxyl group in the complex.

Band II, which caused by the transition $\left(\pi \rightarrow \pi^{*}\right)$ of the aromatic ring, exhibit absorption maxima at $280 \mathrm{~nm}$. This measured wavelength reflect the effect of substitution by auxochromes (hydroxyl group) caused a bathochromic shift in bands I and II, of the complexes [18].

The measurements of the molar electrical conductivity of the complexes in DMSO are indicated that the results clearly show values for the molar conductivity of the complexes of bivalent metals are non- electrolyte. From the above spectroscopic results (IR, UV-VIS) and conductivity measurement the following general structure can be proposed for the metal-Flavone complexes Fig. (1).

\subsection{Antimicrobial Tests}

The activity have been studying for the complexes, in different concentrations and using two types of pathogenic bacteria Escherichia Coli and aurous Staphylococcus. Inhibition zone larger than $6 \mathrm{~mm}$ indicated antimicrobial activity. The complexes showed better efficiency figure (2) for Staphylococcus aurous and Escherichia Col.

A comparison of the value of flavone Ligand with these of the complexes indicates that the metal complexes exhibited higher antibacterial activity then ligand. Such increased activity of the complexes can be explained based on Overtones concept [19] and the tweedy chelation theory [20]. Moreover, the copper complexes were more active than the other complexes against the tested microorganisms as shown in scheme (1).

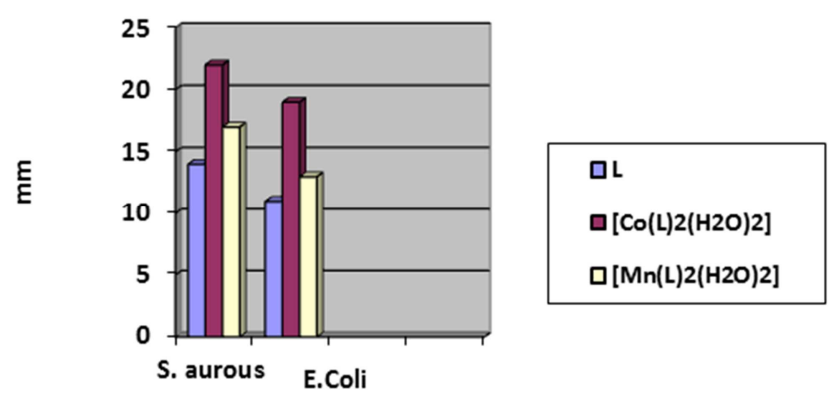

Figure 2. The effect of ligand and their complexes on the growth of bacteria.

\subsection{Study of Cytotoxic Effect}

Cancer cell lines have been used to study the effect of ligand and their complexes on the growth of cells in laboratory to know the specifications of extracts as antitumors. Cancer cell line type Rhabdomyo sarcomas (RD) used with different concentrations comparable with anticancer drug cisplatin as a positive control after $72 \mathrm{hr}$. exposure time.

In this method, we calculate the proportion of cells number within the optimal conditions for growth without the addition of compounds so the output is the control group (control). Then compounds are added for the purpose of knowing their effects on cell growth in elected lines.

The result statistically analyzed by one way ANOVA. the following results as figure (3) which demonstrates the impact of compounds on cells number ratio when using cell line (RD), it is clear that hot alcoholic extract have the greatest influence on the proportion of growth cell number and the effect was significantly ( $\mathrm{P}<0.05$ ). This result is identical to those published in literature [21].

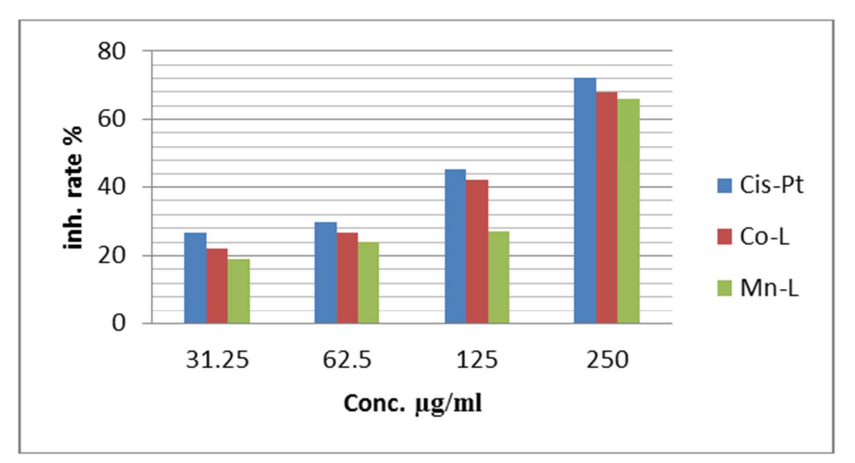

Figure 3. The comparison of inhibition rates between three treatments with cis-pt drug in cell line (RD).

The results in figure (3) shows evidence that new complexes have cytotoxic effect on cancer cell line by elevated of inhibition rates with concentration increased, this effect was similar to effect of anti-cancer cis-platin. In this study, we suggest the new complexes of chalcone ligand have inhibition effect, this effect was similar to Tsuda et al [22] studied on colon and liver cancer in mice and result in DNA damge after shortly administration of relatively high dose, while carcinogenicity was detected after prolong treatment with low doses. Kenyon et al [23] showed the type 
of organic ligand (bis-8-hydroxyquinolin) coupled to tumer cellular copper forming potent protoeasome inhibitors and apoptosis inducers at copper concentration found in tumor tissues. Saadiyh et al [24] showed the new copper complexes and aqueous origanum vulgare extract have a cytotoxic effect on RD cell line in four concentrations. This study similar to our results which rise the inhibition rates with elevation of concentration. The new complexes were similar effect to cispt that could be attributed to the cis-pt binding to and cross linking of DNA which ultimately triggers opoptosis (programmed cell death) $[25,26]$.

\section{Conclusion}

The synthetic and structural study by several spectroscopic techniques of above new type of Octahedral complexes have bidentate ligand. Spectrophotometric solution studies indicate that only a mononuclear complex with 2:1 ligand to metal stoichiometry. The study of biological activity of the ligands and its metal complex against four selected type of bacteria which included (Staphylococcus aureas) as gram positive $(+\mathrm{Ve})$ and (Escherichia Coli) as gram negative (-Ve) to be cultivated and as control for the disc sensitivity test shows that different activity of inhibition on growth of the bacteria. The prepared complexes with Flavon ligand were studied effect on the cancerous cell line RD, it was found that theses ligand and complex have efficacious effects on the cancerous cell.

\section{References}

[1] Hertog, M. G. L.; Feskens, E. J.; Hollman, P. C.; Katan, M. B.; Kromhout, D. Dietary antioxidant flavonoids and risk of coronary heart disease: The Zutphen Elderly Study. Lancet 1993, 342, 1007-1011.

[2] Knekt, P.; Kumpulainen, J.; Jarvinen, R.; Rissanen, H.; Heliovaara, M.; Reunanen, A.; Hakulinen, T.; Aromaa, A. Flavonoid intake and risk of chronic diseases. Am. J. Clin. Nutr. 2002, 76, 560-568.

[3] Cushnie, T.; Lamb, A. Antimicrobial activity of flavonoids. Int. J. Antimicrob. Agents 2005, 26, 343-356.

[4] Ferguson, P. J.; Kurowska, E. M.; Freeman, D. J. In vivo inhibition of growth of human tumor lines by flavonoid fractions from cranberry extract. Nutr. Cancer 2006, 56, 8694.

[5] Jovanovic, S. V.; Steenken, S.; Simic, M. G.; Hara, Y.; Antioxidant properties of flavonoids: Reduction potentials and electron transfer reactions of flavonoid radicals. In Flavonoids in Health and Disease; Rice-Evans, C. A., Packer, L., Eds.; Marcel Dekker, Inc.: New York, NY, 1998; pp. 137-161.

[6] Teixeira S.; Siquet, C.; Aloes, C.; Boal, I.; Marques, M. P.; Borges, F.; Lima, J. L. F. C.; Reis, S. Structure-property studies on the antioxidant activity of flavonoids present in diet. Free Radic. Biol. Med. 2005, 39, 1099-1108.

[7] Pietta, P. G. Flavonoids as Antioxidants. J. Nat. Prod. 2000, 63, 1035-1042.
[8] Van Acker, S. A. B. E.; van Den Berg, D.-J.; Tromp, M. N. J. L.; Griffioen, D. H.; van Bennekom, W. P.; van der Vijgh, W. J. F.; Bast, A. Structural aspects of antioxidant activity of flavonoids. Free Radic. Biol. Med. 1996, 20, 331-342.

[9] van Acker, S. A. B.; van Balen, G. P.; van den Berg, D. J.; Bast, A.; van der Vijgh, W. F. F. Influence of iron chelation on the antioxidant activity of flavonoids. Biochem. Pharmacol. 1998, 56, 935-943.

[10] Grazul, M.; Budzisz, E. Biological activity of metal ions complexes of chromones, coumarins and flavones. Coord. Chem. Rev. 2009, 253, 2588-2598.

[11] Cazarolli, L. H.; Zanatta, L.; Jorge, A. P.; de Sousa, E.; Horst, H.; Woehl, V. M.; Pizzolatti, M. G.; Szpoganicz, B.; Silva, F. R. M. B. Follow-up studies on glycosylated flavonoids and their complexes with vanadium: Their anti- hyperglycemic potential role in diabetes. Chemico-Biol. Interact. 2006, 163, 177-191.

[12] Pereira, R. M. S.; Andrades, N. E. D.; Paulino, N.; Sawaya, A. C. H. F.; Eberlin, M. N.; Marcucci M. C.; Favero, G. M.; Novak, E. M.; Bydlowski, S. P. Synthesis and Characterization of a Metal Complex Containing Naringin and $\mathrm{Cu}$, and its Antioxidant, Antimicrobial, Antiinflammatory and Tumor Cell Cytotoxicity, Molecules 2007, 12, 1352-1366.

[13] Jun, T.; Bochu, W.; Liancai, Z. Hydrolytic cleavage of DNA by quercetin zinc(II) complex. Bioorg. Med. Chem. Lett. 2007, 17, 1197-1199.

[14] Omar H. Al-Obaidi.," Synthesis, Spectral Characterization, Theoretical Evaluation Of New Cr (III), Co (II), Fe(III) And Cu(II) Complexes", App. Sci. Report., 12 (1), 2015: 41-45

[15] Vandpitte J., et al., (1991), "Basic laboratory procedures in clinical bacteriology" WHO., Geneva. (pp 78-110).

[16] Freshney, R. I., "Cultured of Animal Cells: A manual for Basic Techniques “, Inc. Publication, New York, pp 64-69, 2000.

[17] K. Nakmato, Infrared and Raman spectra of Inorganic and coordination compounds, $4^{\text {th }}$ ed., Wiley, New York (1986).

[18] Lever, A. B. P. Inorganic Electronic Spectroscopy; Elsevier: Amsterdam, The Netherlands, 1986; pp. 385-392.

[19] Y. Anjaneyalu, R. P. Rao, Synth. React. Inorg.-Org. chem. 16, 1986, pp. 257. And Maria M. Kasprzak, Andrea Erxleben and Justyn Ochocki, "Properties and applications of flavonoid metal complexes," Review Article 2015. DOI: 10.1039/C5RA05069C

[20] L. Mishra, V. H. Singh, Indian J. Chem. 32A, 1993, pp. 446.

[21] Birt, F. D, Hendrich, S, Wang, W., "Dietary Agents in Cancer Prevention Flavonoids and Isoflavonoids Pharmacology and Therapeutics", USA, pp 157-177, 2001.

[22] Tsuda, S., Matsusaka, N., Madaram H., Ueno, S., Susa, N., Ishida, K., Kawamura, N., Sekihashi, K., Sasak, Y., "the Comet Assay in Eight Mouse Organs Results with 2 Azo Compounds", Mutat. Res., 465, pp 1139-1151, 2000.

[23] Kenyon, G., Puja, G., Harbach, R., Wayne, G., Ping Dou, Q., "Organic Copper Complexes as new Class Of Proteasome Inhibitors and Apoptosis Inducers in Human Cancer Cells," Bioc. Pharm. 67, pp 1139-1151, 2004.

[24] Saadiyah, A. D., Jinan H., and Iman H., J. of Al-Nahrain Univ., 15 (2), pp 23-28, 2012. 
[25] Stordal B., Davey, M.," Vander Standing cisplatin Resistance Using Cellular Models", IUBMB Life, 59, pp 696-9, 2007.

[26] Ikeda NE, Novak EM, Maria DA, Velosa AS, Pereira RM.”
Synthesis, characterization and biological evaluation of Rutinzinc(II) flavonoid -metal complex," Chem Biol Interact. 2015. 5; 239: 184-91. 